\title{
THE EFFECT OF DEPOTOCIN INJ. SPOFA ON CONCENTRATIONS OF CHOLESTEROL, TOTAL LIPIDS, PROGESTERONE AND ON THE CONCEPTION RATE IN POSTPARTURIENT EWES
}

\author{
M. KRAJNIČÁKOVÁ, E. BEKEOVÁ, I. MARAČEK, V. HENDRICHOVSKÝ \\ Research Institute of Experimental Veterinary Medicine, Hlinkova 1/A, 04001 KoSice, Slovak Republic
}

Received May 15, 1995

\begin{abstract}
Krajniçáková M., E. Bekeová, I. Maraček, V. Hendrichovský: The Effect of Depotocin inj. SPOFA on Concentrations of Cholesterol, Total Lipids, Progesterone and on the Conception Rate in Postparturient Ewes. Acta vet. Brno, 1995, 64: 263-268.

The effect of Depotocin inj. Spofa on concentrations of cholesterol, total lipids and progesterone with subsequent synchronization effect on the conception of ewes was studied. A total of 19 ewes were included in the experiment; 10 animals served as a control, and 9 sheep were treated with Depotocin inj. Spofa 2 - 0 - methylthyrosin (deamino -1 - carba) oxytocinum at a dose of $2 \times 0.07 \mathrm{mg}, 24$ and $72 \mathrm{~h}$ after lambing, respectively. Blood samples were obtained from v. jugularis at $36 \mathrm{~h}$ post partum, and on days 4, 7, 14, 17, 21, 25, 34, 42 and 51 after lambing. Agelin vaginal tampons were inserted to sheep of both groups after day 51 ( $20 \mathrm{mg}$ of chlorsuperlutine). Ten days later, the tampons were removed and the animals were injected with $500 \mathrm{I}$. U. of PMSG. The expected date of parturition was calculated from the date of mating. Cholesterol and total lipids were determined using BIO-LA tests (LACHEMA, Brno) and the concentrations of progesterone were determined by the radioimunological method, using kits from ÚRJVT, Košice. Cholesterol concentrations showed no significant differences between the control and experimental groups $(P>0.05)$. The concentrations of total lipids oscillated in the experimental group from day 25 post partum at non-significantly higher values in comparison with the control group by the end of the

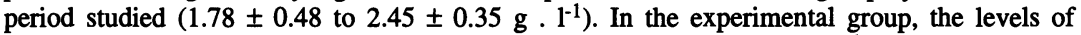
progesterone increased slowly on days 34 and $51\left(0.5 \pm 0.8\right.$ to $\left.0.8 \pm 1.3 \mathrm{nmol} .1^{-1}\right)$. In other sampling days, its values were under the level of sensitivity of the trial. In conclusion, lambing after the oestrus induction on day 51 post partum showed that a $100 \%$ lambing with birth of 16 lambs was achieved in the experimental group whereas in the control group only 5 out of 10 mated animals lambed.
\end{abstract}

Puerperium, ewe, Depotocin, total lipids, cholesterol, progesterone

Puerperium length and course in ewes are extremely important from the point of view of lamb meat and lamb broilers production. In our previous studies (Krajničáková 1990; Krajničáková et al. 1991, 1992), the attention was paid to the physiological course of puerperium and medicamentous influencing of postpartal reparative processes on the reproductive apparatus of sheep following repeated administration of Depotocin inj. Spofa in early puerperium; the authors recorded a $64.3 \%$ decrease in the mass of uterine body and uterine horns as early as on day 7 of the period under study. The effect of repeated administration of Depotocin inj. Spofa on the dynamics of concentration changes of thyroxine, triiodothyronine and ovarian steroids was studied by B ekeová et al. (1992). The authors revealed that the administered carbetocin induces changes in the synthesis and production of both thyroid and steroid hormones through a direct or indirect effect.

Oxytocin, in addition to its uterotonic and luteolytic effect, acts as an ovarian factor in the local interfollicular regulation of steroidogenesis and as a modulator of uterine secretion of prostaglandins as well (Gregoraszcuk et al. 1988; Flint et al. 1990; Light et al. 1994).

The effect of steroid hormones on biosynthesis of prostaglandins can be manifested by the effect of their inhibitors or stimulators of synthetic enzymes. It is assumed that progesterone 
inhibits prostaglandin release by induction of protein synthesis, which in turn inhibits the activity of phospholipase (Th orburn 1979). Stimulation of steroidogenesis by lipoproteins through endocytotic and lysosomal hydrolysis releases cholesterol, which can be the substrate for progesterone synthesis (Rajkumar 1985).

On the basis of the above mentioned studies as well as our previous investigations (Krajničáková et al. 1995), the present study was directed at the determination of the effect of double administration of Depotocin inj. SPOFA on the dynamics of concentration changes in cholesterol, total lipids and progesterone from $36 \mathrm{~h}$ to day 51 after parturition. The effect of Depotocin administration on the conception rate of ewes after the induction of oestrus on day 51 after lambing was studied as well.

\section{Materials and Methods}

\section{Experimental animals}

A total of 19 Slovak Merino ewes weighing 40 to $50 \mathrm{~kg}, 3$ to 5 -year-old, and after 2 to 3 births, that had lambed in the first half of February were included in the experiment. The animals were fed a diet consisting of silage, beet, hay and supplementation of the BAK feeding mixture. Water and salt were provided ad libitum.

\section{Treatment}

Nine sheep were included in the experimental group, and 10 sheep served as a control. The experimental ewes were subjected to treatment with carbetocin 2-0-methyltyroxin (deamino-1-carbo) oxytocinum at a dose of $2 \times 0.07 \mathrm{mg}$ per animal. The first dose was injected intramuscularly (i. m.) $24 \mathrm{~h}$, the second one subcutaneously (s.c.) $72 \mathrm{~h}$ after parturition. On day 51 after parturition, after the weaning of lambs, oestrus was induced in ewes of both control and experimental groups by insertion of vaginal polyurethane tampons containing $20 \mathrm{mg}$ of chlorsuperlutine (Agelin - vaginal tampons, Spofa). After 10 days the tampons were removed and the animals were administered 500 I. U. of PMSG. From the day of PMSG administration, sheep were kept together with rams for the following 6 days. The expected date of parturition was calculated according to the date of mating. According to the number of lambed animals, the conception rate in two observed groups was determined.

\section{S a m pling}

Blood samples were obtained by puncture of the $v$. jugularis $36 \mathrm{~h}$ after lambing and on days $4,7,14,17,21,25$, 34,42 and 51 post partum between 9.00 and $10.00 \mathrm{~h}$. The days of sampling were determined according to the schedule of the experiment as well as the other indices, mainly functional-morphological ones, taking into account the termination of the involution process of endometrium and postparturient recovery of ovarian functions. The blood sera obtained by centrifugation were stored in polyurethane tubes at $-18 \mathrm{oC}$ until processing.

\section{Analytical methods}

Cholesterol, total lipids and progesterone were determined in the blood serum. Concentrations of cholesterol and total lipids were determined by means of BIO-La tests (Lachema Brno). The levels of progesterone were determined by RIA-test-Prog kits (ÚRVJT Košice, Slovak Republic). The determinations were carried out directly, without extraction, in duplicates in $0.05 \mathrm{ml}$ of serum. The declared test sensitivity was $0.5 \mathrm{nmol} .1^{-1}$. The intra-assay (five determinations for each of two pools containi ng $4.813 \mathrm{Z} 0.66$ and $44.17 \mathrm{Z} 1.85 \mathrm{nmol} .1-1$ ) was $13.71 \%$ and $4.18 \%$, respectively. The inter-assay (ten and six determinations for each of two pools containing $4.81 \mathrm{Z} 0.36$ and $44.96 \mathrm{Z} 1.92 \mathrm{nmol}^{-1} \mathrm{I}^{-1}$ ) was $7.48 \%$ and $4.27 \%$, respectively. The test recovery ranged from 90 to $110 \%$.

\section{Statistical methods}

The significance of the parameters observed between $36 \mathrm{~h}$ and other days of the experiment, as well as the significance of differences between groups were determined by Student's t-test.

\section{Results}

In the control group, the concentrations of cholesterol (Table 1) ranged from $1.56 \pm 0.27$ to $2.10 \pm 0.53 \mathrm{mmol} . \mathrm{l}^{-1}$.

In the experimental group (the administration of Depotocin inj. SPOFA) the levels of cholesterol were nearly the same up to day 7 after lambing $\left(2.13 \pm 0.18-2.08 \pm 0.38 \mathrm{mmol} . \mathrm{l}^{-1}\right)$. A significant decrease $(\mathrm{P}<0.01)$ in its levels as compared to day 0 was recorded at 
$1.68 \pm 0.21 \mathrm{mmol}^{-1}$ ) on days 14 and 21 as well as on days 17 and 42 of the experiment $(\mathrm{P}<0.05)$. Observation of the total lipids in the control group (Table 1) showed the significant increase $(\mathrm{P}<0.01)$ in their levels on days 4 and 7 in comparison with $36 \mathrm{~h}$ after lambing (day 0 ). Their slight decrease to $1.87 \pm 0.67 \mathrm{~g}^{-1^{-1}}$ on day 14 was replaced by significant increase $(\mathrm{P}<0.001)$, on days 17 and 21 of the period studied. A significant increase $(\mathrm{P}<0.05)$ was found also on days 25,34 and 42 of the postpartal period.

Table 1

Concentrations of cholesterol, total lipids and progesterone in the puerperium of sheep after administration of Depotocin inj. SPOFA

\begin{tabular}{|c|c|c|c|}
\hline $\begin{array}{l}\text { Day post } \\
\text { partum }\end{array}$ & $\begin{array}{l}\text { Cholesterol } \\
\left(\mathrm{mmol} .^{-1}\right)\end{array}$ & $\begin{array}{c}\text { Control group } \\
\text { Total Lipids (g.1-1) }\end{array}$ & $\begin{array}{l}\text { Progesterone }\left(\mathbf{P}_{4}\right) \\
\left(\mathrm{nmol} . \mathrm{I}^{-1}\right)\end{array}$ \\
\hline $36 \mathrm{~h}$ & $1.92 \pm 0.39$ & $1.25 \pm 0.39^{\mathrm{b}}$ & - \\
\hline d 4 & $2.10 \pm 0.53$ & $2.16 \pm 0.57^{\mathrm{xx}}$ & - \\
\hline 7 & $1.90 \pm 0.32$ & $2.15 \pm 0.58^{\mathrm{xx}}$ & - \\
\hline 14 & $1.68 \pm 0.21$ & $1.87 \pm 0.67$ & - \\
\hline 17 & $1.74 \pm 0.33$ & $2.42 \pm 0.41^{\mathrm{xxxa}}$ & - \\
\hline 21 & $1.86 \pm 0.42$ & $2.15 \pm 0.22^{\mathrm{xxx}}$ & - \\
\hline 25 & $1.56 \pm 0.27$ & $1.84 \pm 0.34^{x}$ & - \\
\hline 34 & $2.01 \pm 0.42$ & $2.01 \pm 0.58^{x}$ & $1.00 \pm 2.80$ \\
\hline 42 & $1.74 \pm 0.33$ & $1.83 \pm 0.46^{x}$ & - \\
\hline 51 & $1.74 \pm 0.46$ & $1.62 \pm 0.37$ & - \\
\hline \multicolumn{4}{|c|}{ Experimental group } \\
\hline $36 \mathrm{~h}$ & $2.13 \pm 0.18$ & $2.35 \pm 0.39^{b^{\prime}}$ & $1.40 \pm 0.90$ \\
\hline d 4 & $2.08 \pm 0.38$ & $2.01 \pm 0.29$ & - \\
\hline 7 & $2.08 \pm 0.32$ & $2.28 \pm 0.58$ & - \\
\hline 14 & $1.68 \pm 0.18^{\mathrm{xx}}$ & $1.70 \pm 0.27^{\mathrm{xx}}$ & - \\
\hline 17 & $1.77 \pm 0.30^{x}$ & $1.78 \pm 0.48^{\times \mathrm{a}^{\prime}}$ & - \\
\hline 21 & $1.68 \pm 0.21^{x x}$ & $1.88 \pm 0.49$ & - \\
\hline 25 & $1.89 \pm 0.30$ & $2.18 \pm 0.48$ & - \\
\hline 34 & $1.79 \pm 0.35$ & $2.45 \pm 0.35$ & $0.50 \pm 0.80$ \\
\hline 42 & $1.76 \pm 0.27^{x}$ & $2.13 \pm 0.30$ & - \\
\hline 51 & $1.81 \pm 0.34$ & $2.07 \pm 0.59$ & $0.80 \pm 1.30$ \\
\hline
\end{tabular}

The significance compared to $36 \mathrm{~h}$ post partum $\mathrm{x}=\mathrm{P}<0.05 ; \mathrm{xx}=\mathrm{P}<0.01 ; \mathrm{xxx}=\mathrm{P}<0.001$.

The significance in intergroup differences $\mathrm{a}: \mathrm{a}^{\prime}=\mathrm{P}<0.05$;

$\mathrm{b}^{\prime} \mathrm{b}^{\prime}=\mathrm{P}<0.01$

In the experimental group, the concentrations of total lipids from $36 \mathrm{~h}$ up to day 7 after lambing ranged from $2.01 \pm 0.29$ to $2.35 \pm 0.39 \mathrm{~g} . \mathrm{l}^{-1}$. The significant decrease in their concentrations with the lowest levels $\left(1.70 \pm 0.27 \mathrm{~g} . \mathrm{l}^{-1}\right)$ was found on day $14(\mathrm{P}<0.01)$ and day $17(\mathrm{P}<0.05)$ p. p. From the 25th day to the end of the observed period, their concentrations ranged from $2.07 \pm 0.59$ to $2.45 \pm 0.35 \mathrm{~g} . \mathrm{l}^{-1}$ while their dynamics showed slightly decreasing tendency from day 34 to day 51 of th e period studied.

The concentrations of progesterone (P4) in the control group post partum (Table 1) ranged below the level of sensitivity except for day 34 after parturition, with widely dispersed individual values. In the experimental group of ewes (Table 1), its levels gradually increased on days 34 and 51 .

Significant differences between groups in concentrations of total lipids were recorded at $36 \mathrm{~h}(\mathrm{P}<0.001)$ and on $\mathrm{d} 17(\mathrm{P}<0.05)$ of the postpartal period. No significant differences in cholesterol levels were recorded between groups. 
Table 2

Fertility parameters of sheep after the effect of Depotocin inj. SPOFA on their puerperium

\begin{tabular}{|lcc|}
\hline \multicolumn{1}{|c}{ Indicator } & $\begin{array}{c}\text { Ewes without } \\
\text { treatment }\end{array}$ & $\begin{array}{c}\text { Ewes treated with Depotocin } \\
\text { at 24 and 72 h p. p. }\end{array}$ \\
\hline Number of sheep prepared for mating & 10 & 9 \\
Number of lambed out of mated sheep & 5 & 9 \\
\% of lambed sheep & 50.00 & $100 \%$ \\
Numbers of born lambs & 6 & 16 \\
Lambs-Ewes & 2 & 7 \\
Lambs-Rams & 4 & 9 \\
\hline
\end{tabular}

Evaluation of the results of the lambing (Table 2) after induction of the oestrus on day 51 post partum showed that out of 10 animals, 5 ewes lambed giving birth to 6 lambs in the control group. In the experimental group, all 9 treated sheep lambed and gave birth to 16 lambs.

\section{Discussion}

Evaluation of the concentrations of cholesterol showed no significant differences between experimental and control groups. These data ara comparable with the results obtained by Krajničáková et al. (1995) after the administration of gonadoliberin in the first phase of the postpartal period. In the experimental group, its significant decrease was recorded (administration of carbetocin, Depotocin inj. SPOFA) on days 14 and $21(\mathrm{P}<0.001)$ and on days 17 and $42(\mathrm{P}<0.05)$ of the period studied. From the literature data of Brown et al. (1981) it is evident that with the decreased cholesterol concentrations, a low-density lipoproteins decrease occurred. Metabolism of low-density lipoproteins is closely connected with the effect of estrogens and its ability to maintain the production of oxytocin receptors, with subsequent stimulatory effect on the system of prostaglandins through the increased activity of phospholipases (Thorburn 1979). Taking into account that the production of cholesterol that is the primary substrate of progesterone may depend also on LH as well as phospholipase regulation, then it is likely that the exogenous administration of carbetocin with its positive effect on prostaglandin synthesis did not influence the concentrations of cholesterol in the puerperium found by us.

In the experimental group, after a significant decrease $(\mathrm{P}<0.01)$ on days 14 and 17 $(\mathrm{P}<0.05)$ p. p. the concentrations of total lipids were insignificantly higher by the end of the period studied in comparison with the control group. In the metabolism of lipids, the effect of hormones can be manifested indirectly, too, i. e. by the subsequent action of endocrine lipolytic factors, which have either an inhibitory or stimulative effect on the lipase activity.

Repeated administration of Depotocin to the animals in our experiment presents one alternative to stimulate the synthesis of prostaglandins; the question, to what extent the fatty acids accumulating during the inhibitory phase of progesterone perform their function, just by means of prostaglandin synthesis, is still difficult to answer. The assumed increase in the concentration of prostaglandins after exogenous supply of Depotocin might lead also to the stimulation of other endocrine lipolytic factors which could consequently influence the dynamic changes of the lipid concentrations found in the experimental group in the period studied via the increased activity of enzymatic systems, in addition to the effect on the production of androgens and their aromatization (Dodson et Wats on 1980).

In the control group, the levels of progesterone episodically increased on day 34 after parturition. In the experimental group, its levels close above the level of sensitivity of the trial were recorded on days 34 and 51. In next days, its average values were below $0.5 \mathrm{nmol.} .^{-1}$ of the serum. It is in agreement with the findings of Bekeová et al. (1992); 
Krajničáková et al. (1994) in sheep, and Kudlác and Píchová (1990); Dimmick et al. (1991), Zralý et al. (1989) by day 15 after the parturition of cows. According to Burd et al. (1976) the decrease in the levels of progesterone and oestradiol post partum to zero is connected with postparturient extinction of the fetoplacental unit and with response of adenohypophysis on hormonal treatment of ewes in the above mentioned period. From the experimental work of Schirar et al.(1989); Greyling and Van Niekerk (1991); Krajničáková et al.(1992) it is evident that the postparturient ovarian activity in sheep depends, to a great extent, on the uterine involution processes. The results obtained concerning the fertility in sheep observed in our experiment, presented in Table 2, are comparable to those of Ainsworth et al. (1982), Krajničáková et al. (1992) about the termination of involution processes, which have a favourable effect on the nidation of the ovum of mated sheep.

These results contribute to the knowledge about the puerperium of ewes and they point out to their functional importance in the utilization of biotechnical methods and techniques in the control of puerperium. The administration of an uterotonic preparation, in addition to its effect on reparation and involution processes of sexual apparatus, via enzymatic systems involved in the steroidogenesis influenced the protein and lipid metabolism with subsequent effect on the conception rates of ewes.

\section{Vplyv Depotocinu inj. SPOFA na koncentrácie cholesterolu, celkových lipidov, progesteronu a na koncepciu bahníc po pôrode}

V práci sme sa zamerali na sledovanie úcinku Depotocinu inj. Spofa na koncentrácie cholesterolu, celkových lipidov a progesterónu s následným synchronizačným efektom na koncepciu bahníc. V experimente bolo zaradených 19 bahníc, z ktorých 10 slúžilo ako kontrola. Deviätim ovciam sme 24 a $72 \mathrm{~h}$ po vybahnení aplikovali $2 \times 0.07 \mathrm{mg}$ Depotocinu inj. Spofa 2-0-methyltyrosin (deamino-1-karba) oxytocinum. Vzorky krvi boli odobrané $\mathrm{z}$ v. jugularis $\mathrm{v} 36 \mathrm{~h}$ po pôrode, 4., 7., 14., 17., 21., 25., 34., 42. a 51. deň po vybahnení. Ovciam obidvoch skupín sme po 51. dni aplikovali Agelin pošvové tampóny ( $20 \mathrm{mg}$ chlórsuperlutínu). Po 10-tich dňoch sme tampóny odstránili a zvieratám aplikovali $500 \mathrm{~m} . \mathrm{j}$. PMSG. Očakávaný termín pôrodu sme určili od dátumu pripustenia. Cholesterol, celkové lipidy sme stanovili pomocou BIO-LACHEMA testov (LACHEMA, Brno) a koncentrácie progesterónu rádioimunologicky, súpravami ÚRVJT, Košice. Pri hodnotení koncentrácií cholesterolu sme štatisticky významné rozdiely medzi kontrolnou a pokusnou skupinou nezaznamenali $(\mathrm{P}>0.05)$. Koncentrácie celkových lipidov sa od 25 . dňa po pôrode pohybovali na nesignifikantne vyšsích hodnotách v pokusnej oproti kontrolnej skupine zvierat do konca sledovaného obdobia ( $1.78 \pm 0.48-2.45 \pm 0.35$ g.l $\left.1^{-1}\right)$. Pri koncentráciách progesterónu sme $\mathrm{v}$ pokusnej skupine zaznamenali $\mathrm{v} 34$. a 51 . dni pozvolný vzostup $(0.5 \pm 0.8$ až $\left.0.8 \pm 1.3 \mathrm{nmol} . \mathrm{l}^{-1}\right)$.V ostatných dřoch sa pohybovali jeho hodnoty pod hladinou citlivosti skúšky. Pri hodnotení výsledkov bahnenia po navodení ruje v 51. dni po pôrode sa $\mathrm{v}$ kontrolnej skupine obahnilo 5 zvierat a v pokusnej skupine z 9 ošetrených sme dosiahli $100 \%$ bahnenie s uliahnutím 16 jahniat.

\section{References}

AINSWOTH, L., LACHENCE, R., LABRIE, F. 1982: Effect of GnRH induced endogenous luteinizing hormone release and endogenous progestagen treatment on ovarian activity in the post partum ewe. J. Anim. Sci. 54:9981004

BEKEOVÁ, E., KRAJNIČÁKOVÁ, M., HENDRICHOVSKÝ, V., MARAČEK, I. 1992: Vztah medzi hmotnostou maternice a vaječníkov a hladinami ovariálnych a tyroidálnych hormónov u bahníc $\mathrm{v}$ puerpériu po ošetrení carbetocínom (DEPOTOCIN INJ. SPOFA). Živ. výroba 37:587-600 
BROWN, M. S., KOVAVEN, P. T., GOLDSTEIN, I. L. 1981: Regulation of plasma cholesterol by lipoprotein receptors. Science 212:628-635

BURD, L. L., LEMONS, J. A., MAKOWSKI, E. L., MESCHIA, G. A., NISWENDER, G. 1976: Mammary blood flow and endocrine changes during parturition in the ewe. Endocrinol. 98:748-754

DIMMICK, M. A., GIMENEZ, T., SPITZER, J. C. 1991: Ovarian endocrine activity and development of ovarian follicles during the post partum interval in beef cows. Anim. Reprod. Sci. 24:173-183

DODSON, K.S., WATSON, J. 1980: Stimulatory action of prostaglandin F2alfa on androgen aromatization in the pig follicle. Eur. J. Obstet. Gynec. Reprod.B iol. 11:49-56

FLINT, A. P. F., SHELDRICK, E. L., Mc CANN, T. J., JONES, D. S. C. 1990: Luteal oxytocin: characteristics control of synchronous episodes of oxytocin and PGF2alfa secretion at luteolysis in ruminants. Dom. Anim. Endocrinol. 7:111-124

GREGORASZCUK, E., STOKLOSOVÁ, S., TARNAWSKA, M., RZASA, J. 1988: The effect of oxytocin on steroid hormone secretion by isolated porcine follicular cells in tissue culture. Anim. Reprod. Sci. 17:141-154

GREYLING, J. P. C., VAN NIEKERK, C. H. 1991: Involution of the post partum uterus of the Boer goat. J. S. Afr . Veter. Assoc. 62:4-9

KRAJNIČÁKOVÁ, M., ELEČKO, J., BEKEOVÁ, E., MARAČEK, I., HENDRICHOVSKÝ, V. 1990: Biometrické parametre maternice vaječníkov a koncentrácie 17 beta estradiolu (E2) po porode oviec. Vet. Med. - Czech 35:747-756

KRAJNIČÁKOVÁ, M., ELEČKO, J., BEKEOVÁ, E., MARAČ́EK, I., HENDRICHOVSKÝ, V. 1991: Biometrické parametre maternice a vaječníkov po aplikácii Depotocínu inj. Spofa v ranom puerpériu oviec. Vet. Med.- Czech 36:607-618

KRAJNIČÁKOVÁ, J., BEKEOVÁ, E., MARAČEK, I., HENDRICHOVSKÝ, V. 1992: Zmeny hmotnosti vaječníkov a počty povrchových folikulov po aplikácii Depotocínu inj. Spofa v puerperálnom období bahníc. Živ. výroba 37:385-391

KRAJNIČÁKOVÁ, J., BEKEOVÁ, E., MARAČEK, I., HENDRICHOVSKÝ, V. 1994: Koncentrácie cholesterolu, celkových lipidov a progesterónu v puerperálnom období bahníc. Živ. výroba 39:1035-1040

KRAJNIČÁKOVÁ, J., BEKEOVÁ, E., MARAČEK, I., HENDRICHOVSKÝ, V. 1995: Vplyv opakovanej aplikácie GnRH (Dirigestran inj. Spofa) a Folicotropínu na koncentrácie cholesterolu, celkových lipidov a progesterónu v puerperálnom období bahníc. Živ. výroba 40: 65-70

KUDLÁČ, E., PICHOVÁ, D. 1990: Responze adenohypofýzy a úcinnost aplikace syntetického GnRH (Dirigestran inj. Spofa) u krav post partum. Vet. Med. - Czech 35: 321-330

LIGHT, J. E., SILVIA,W. J., REID, R. C. 1994: Luteolytic Effect of Prostaglandin F2alfa and Two Metabolites in Ewes. J. Anim. Sci. 72: 2718 - 2721

RAJKUMAR, K., COUNTURE, R. L., MURPHY, B. D. 1985: Binding of high density lipoproteins to luteal membranes: the role of prolactin LH and circulating lipoproteins. Biol. Reprod. 32:546-553

SCHIRAR, A., COGNIE, Y., LOVAULT, F., POULIN, N., MEUSNIER, C., LEVASSEUR, M. C., MARTINET, J. 1989: Resumption of gonadotrophin release during the post-partum period in suckling ewes. J. Reprod. Fertil. 88:593-604

THORBURN, G. D. 1979: Endocrine control of parturition. Physiol. Reviews 59: 863

ZRALÝ, Z., KALÁB, P., ĆANDERLE, J., KUMMER, V., RASZYK, J. 1989: Koncentrace progesteronu, 17 betaestradiolu a 11 hydroxykortikosteroidủ v krevní plazmě krav při rozdílném prüběhu puerperia. Vet. Med. - Czech 34:515-525

\section{Acknowledgement}

The authors wish to thank Mrs. Vlasta Novotna for translating the manuscript into English. 